\title{
KAJIAN REVISI PERATURAN KEPALA BATAN TENTANG PEDOMAN PENILAIAN RISIKO KESELAMATAN DAN KESEHATAN KERJA
}

\section{REVIEW OF BATAN HEAD REGULATION REVISION CONCERNING GUIDELINES FOR WORK SAFETY AND HEALTH RISK ASSESSMENT}

\author{
W. Prasuad ${ }^{1}$, Edison Sihombing ${ }^{2}$ \\ 1,2 BATAN, PRSG, Puspiptek, Tangerang Selatan 15314 \\ E-mail: prasuad@batan.go.id
}

Diterima : 30 Juli 2019, diperbaiki : 12 Agustus 2019, disetujui : 10 September 2019

\begin{abstract}
ABSTRAK
KAJIAN REVISI PERATURAN KEPALA BATAN TENTANG PEDOMAN PENILAIAN RISIKO KESELAMATAN DAN KESEHATAN KERJA. Badan Tenaga Nuklir Nasional sebagai badan pengoperasi fasilitas nuklir maupun non nuklir selalu sangat memprioritaskan keselamatan dalam setiap kegiatannya. Menyadari adanya perkembangan kegiatan pengoperasian fasilitas serta waktu pemberlakuan Perka Batan No. 020/KA/I/2012 yang sudah memasuki tahap revisi, maka Perka ini perlu dilakukan revisi. Namun, sebelum revisi perlu dilakukan kajian terhadap perkembangan kegiatan pengoperasian fasilitas dan studi pustaka agar kajian yang dilakukan sesuai dengan kebutuhan dan perkembangan yang ada. Kajian pada revisi ini difokuskan pada adanya perubahan pada skala konsekuensi dan nilai pada skala risiko. Adanya perubahan dari 5 (lima) skala konsekuensi menjadi 3 (tiga) skala konsekuesi hal ini akan mengakibatkan perubahan pada penilaian pemeringkatan risiko pada suatu aktivitas. Dengan 3 (tiga) konsekuensi maka perhitungan risiko harus dibuat dengan lebih seksama karena akan sangat berpengaruh besar terhadap nilai perhitungan skala risiko, tindakan yang akan diterima, pengendaliannya maupun dampak tidak langsung terhadap penguatan SMK3 dan Budaya Keselamatan. Dengan perubahan konsekuensi 5 (lima) menjadi 3, maka diperlukan penentuan peluang lebih cermat, agar profil risiko masih dapat diterima.
\end{abstract}

Kata kunci: SMK3, HIRADC, penilaian risiko, skala perhitungan risiko

\begin{abstract}
REVIEW OF BATAN HEAD REGULATION REVIEW ON GUIDELINES FOR SAFETY AND HEALTH RISK ASSESSMENT. The National Nuclear Energy Agency, as the operating body for nuclear and non-nuclear facilities, always prioritizes safety in all its activities. Be aware of the development of facility operation activities and the time of enactment of Regulation No. Batan. 020 / KA / I / 2012 which has entered the revision stage, then this Perka needs to be revised. However, prior to revision, it is necessary to conduct a study of the development of facilities and library study activities so that the studies conducted are in accordance with the existing needs and developments. The review on this revision focuses on changes in the scale of consequences and the value on the scale of risk. A change from 5 (five) consequence scale to 3 (three) consequence scales will result in a change in the risk rating assessment of an activity. With 3 (three) consequences, the risk calculation must be made more carefully
\end{abstract}


because it will greatly influence the value of the calculation of the risk scale, the actions to be received, its control and the indirect impact on strengthening SMK3 and Safety Culture. With the change in consequences of 5 (five) to 3, it is necessary to determine opportunities more carefully, so that the risk profile can still be accepted.

\section{Keywords: SMK3, HIRADC, , risk assessment, scale of risk calculation}

\section{PENDAHULUAN}

7 dentifikasi bahaya dan penilaian risiko yang lebih popular dikenal sebagai Hazard Identification Risk Assessment Determination And Control (HIRADC) yang terkait dengan setiap aktifitas di fasilitas dalam suatu organisasi harus dipastikan sesuai, cukup dan selalu tersedia. Oleh sebab itu Organisasi/Satuan Kerja harus mengidentifikasi, mengevaluasi dan mengendalikan risiko keselamatan dan kesehatan kerja (K3) di setiap kegiatannya baik rutin maupun non-rutin.

Berdasarkan Bab 2 (dua) Standar BATAN SB006OHSAS 18001:2008 Tahun 2008 tentang pedoman persyaratan sistem manajemen keselamatan dan kesehatan kerja (SMK3) disebutkan bahwa setiap Unit Kerja yang telah mengimplementasikan standar ini harus memastikan bahwa organisasi sudah melaksanakan peninjauan awal kondisi keselamatan dan kesehatan kerja (K3) organisasi saat sebelum menerapkan standar ini[1].

Peninjauan awal kondisi K3 organisasi dilakukan dengan cara:

- identifikasi kondisi yang ada dibandingkan dengan butir-butir yang relevan pada SMK3 ini:

- identifikasi sumber bahaya yang berkaitan dengan kegiatan organisasi;

- penilaian tingkat pengetahuan, pemenuhan peraturan perundangan dan standar K3;

- membandingkan penerapan K3 dengan organisasi dan sektor lain yang lebih baik;
- meninjau sebab dan akibat kejadian yang membahayakan, kompensasi dan gangguan, serta

- hasil penilaian sebelumnya yang berkaitan dengan K3 dan menilai efektivitas dan efisiensi sumber daya yang disediakan.

Hal ini juga sesuai Peraturan Pemerintah No. 50 Tahun 012 tentang Penerapan Sistem Keselamatan dan Kesehatan Kerja (SMK3) ${ }^{[2]}$. Dalam peraturan tersebut pada lampiran II klausul 2.1.2 menyebutkan bahwa identifikasi potensi bahaya, penilaian dan pengendalian risiko K3 harus dipertimbangkan pada saat merumuskan strategi rencana K3 yang menyatakan bahwa perlu dilakukan perhitungan risiko kecelakaan melalui identifikasi sumber bahaya, analisis dan pengendalian risiko oleh petugas yang berkompeten. Pengaturan secara teknis untuk melakukan identifikasi bahaya dan penilaian risiko ini sebelumnya diatur pada Peraturan Kepala Batan No. 020//KA/I/2012 ${ }^{[3]}$ tentang Pedoman Penilaian Risiko Keselamatan dan Kesehatan Kerja. Peraturan tersebut saat ini sedang direvisi dan dicabut dengan Peraturan Batan no 5 tahun 2019.

Tujuan penulisan makalah ini akan diuraikan tentang perubahan terhadap pemeringkatan risiko berdasarkan rencana rumusan yang baru sehingga akan membantu para pihak yang berkepentingan dalam melaksanakan maupun menilai terhadap pelaksanaannya di fasilitas. Perubahan ini juga memberikan penguatan pada peran prilaku aman dan selamat pegawai dalam bekerja di daerah radiasi sehingga akan 
bermuara pada kepatuhan terhadap SOP dan menguatnya Budaya Keselamatan Unit Kerja ${ }^{[4]}$.

Untuk memudahkan dalam memahami kajian ini maka tahapan penulisan kajian ini akan di buat berdasarkan perubahan yang terjadi pada Perka ini serta akibat perubahan yang akan mempengaruhi pemeringkatan. Dengan adanya perubahan penilaian pada skala dan besaran konsekuensinya maka perlu dilakukan perubahan pada dokumen HIRADC yang pernah dibuat. Dengan perubahan pada skala dan besaran konsekuensinya, merupakan kesempatan bagi Unit Kerja untuk menilai ulang konsekuensi, sehingga perubahan yang ada pada proses/teknologi akan memperoleh penilaian risiko yang lebih akurat serta cara penanganannya.

\section{METODOLOGI}

Dasar kajian pada makalah ini adalah draft revisi Peraturan Batan tentang pedoman penilaian risiko $\mathrm{K} 3$. Dengan adanya revisi perubahan pada konsekuensi (K) dari 5 (lima) menjadi 3 pada, maka akan ada perubahan mendasar dalam perhitungan nilai profil pada pemeringkatan risiko. Dengan membuat penetapan nilai konsekuensi yang tepat, maka kegiatan dapat dilakukan dengan pengendalian yang sesuai. Untuk mengetahui perubahan nilai profil pemeringkatan risiko akibat revisi yang akan dilakukan, digunakan contoh HIRADC dari PRSG dengan fokus pada aktivitas yang berpotensi menerima paparan radiasi atau derah kerja radiasi.

\section{TINJAUAN PUSTAKA}

Risiko adalah suatu kemungkinan terjadinya bahaya atau paparan dengan keparahan dari cedera atau gangguan kesehatan yang disebabkan oleh kejadian atau paparan tersebut. Tujuan dan upaya K3 adalah untuk mencegah kecelakaan yang ditimbulkan karena adanya suatu bahaya di lingkungan kerja. Oleh karena itu pengembangan sistem manajemen $\mathrm{K} 3$ harus berbasis pengendalian risiko sesuai dengan sifat dan kondisi bahaya yang ada.Tahapan penilaian risiko dapat disederhanakan menjadi 3 (tiga bagian) utama yaitu, Identifikasi bahaya (I), Peluang terjadinya risiko $(\mathrm{P})$ dan skala Konsekuensi $(\mathrm{K})$.

Untuk menghitung Risiko ( $R$ ) berdasarkan kontribusi besarnya peluang terjadinya risiko $(P)$ menggunakan Tabel 1 , sedangkan untuk skala Konsekuensi (K) dapat di lihat pada Tabel 2 . Kombinasi ketiganya inilah yang sangat menentukan dalam membuat perhitungan Risiko (R).

Tabel 1. Skala peluang terjadinya risiko ${ }^{[3]}$

\begin{tabular}{cll}
\hline \multirow{2}{*}{ Skala } & \multicolumn{1}{c}{ Sifat } \\
\cline { 2 - 3 } & \multicolumn{1}{c}{ Rutin } & \multicolumn{1}{c}{ Non-rutin } \\
\hline 1 & $\begin{array}{l}\text { Secara teori bisa terjadi, tetapi belum } \\
\text { pernah mengalami atau pernah } \\
\text { mendengar terjadi }\end{array}$ & $\begin{array}{l}\text { Secara teori bisa terjadi, } \\
\text { tetapi yakin tidak akan terjadi selama } \\
\text { pekerjaan berlangsung }\end{array}$ \\
\hline 2 & $\begin{array}{l}\text { Pernah terjadi 1 (satu) kali pada suatu } \\
\text { waktu yang tidak diketahui dengan pasti, } \\
\text { di atas 5 (lima) tahun }\end{array}$ & $\begin{array}{l}\text { Bisa terjadi tetapi sangat kecil } \\
\text { kemungkinan akan terjadi 1 (satu) kali } \\
\text { selama pekerjaan berlangsung }\end{array}$ \\
\hline
\end{tabular}


Tabel 1. Lanjutan

\begin{tabular}{cllll}
\hline \multirow{2}{*}{ Skala } & \multicolumn{3}{c}{ Sifat } \\
\cline { 2 - 5 } & \multicolumn{2}{c}{ Rutin } & \multicolumn{1}{c}{ Non-rutin } \\
\hline 3 & $\begin{array}{l}\text { Pernah terjadi dalam waktu } \\
\text { tahun terakhir }\end{array}$ & (lima) & $\begin{array}{l}\text { Bisa terjadi paling banyak 1 (satu) kali } \\
\text { selama pekerjaan berlangsung }\end{array}$ \\
\hline 4 & $\begin{array}{l}\text { Pernah terjadi dalam waktu 3 (tiga) tahun } \\
\text { terakhir }\end{array}$ & $\begin{array}{l}\text { Bisa terjadi 2 (dua) sampai 3 (tiga) } \\
\text { kali selama pekerjaan berlangsung }\end{array}$ \\
\hline 5 & $\begin{array}{l}\text { Pernah terjadi dalam waktu } \\
\text { tahun terakhir }\end{array}$ & 1 (satu) & $\begin{array}{l}\text { Bisa terjadi lebih dari 3 (tiga) kali } \\
\text { selama pekerjaan berlangsung }\end{array}$ \\
\hline
\end{tabular}

Rumusan untuk menghitung nilai $R$ untuk mengetahui pemeringkatan risiko pekerjaan atau aktivitas dituliskan pada pers.1 sebagai hubungan linier antara peluang $(\mathrm{P})$ dan Konsekuensi $(\mathrm{K})$

$\mathbf{R}=\mathbf{P} \times(\Sigma K)$

Dengan :

$\mathrm{R}=$ resiko

$\mathrm{P}=$ peluang peluang terjadinya risiko (Tabel 1);

$\mathrm{K}=$ konsekuensi (Tabel 2) dan

$\Sigma \mathrm{K}=$ jumlah $\mathrm{K} 1+\mathrm{K} 2+\mathrm{K} 3+\mathrm{K} 4+\mathrm{K} 5$

Tabel 2. Penentuan skala konsekuensi

\begin{tabular}{|c|c|c|c|}
\hline \multicolumn{4}{|c|}{ Kategori } \\
\hline $\begin{array}{c}\text { Dampak } \\
\text { K3 } \\
\text { (K1) }\end{array}$ & $\begin{array}{l}\text { Kondisi } \\
\text { daerah kerja } \\
\text { radiasi } \\
\left(\mathbf{K}_{\mathbf{2}}\right)\end{array}$ & $\begin{array}{l}\text { Penerima an } \\
\text { dosis individu } \\
\text { (K3) }\end{array}$ & $\begin{array}{l}\text { Lingkungan hidup } \\
\text { (K4) }\end{array}$ \\
\hline Tindakan P3K & $\leq 5 \mathrm{mSv}$ pertahun & $\leq 20 \mathrm{mSv}$ pertahun & $\begin{array}{c}<\text { BML (baku mutu } \\
\text { lingkungan) }\end{array}$ \\
\hline $\begin{array}{l}\text { Perawa tan } \\
\text { medis }\end{array}$ & $\begin{array}{c}5<\text { dosis } \\
\leq 15 \mathrm{mSv} \text { pertahun }\end{array}$ & $\begin{array}{c}20<\text { dosis } \leq \\
200 \text { mSv ertahun }\end{array}$ & $\begin{array}{l}\text { Dapat pulih dengan sendiri } 5 \% \leq X<15 \% \\
\text { nya }<12 \text { bulan }\end{array}$ \\
\hline $\begin{array}{l}\text { Cacat Per } \\
\text { Manen } 1 \text { orang }\end{array}$ & $\begin{array}{l}15<\text { dosis } \\
<50 \text { mSv } \\
\text { pertahun }\end{array}$ & $\begin{array}{l}200<\text { dosis } \\
\leq 500 \text { mSv per } \\
\text { tahun }\end{array}$ & $\begin{array}{l}\text { Dapat dipulihkan dengan } 15 \% \leq X<30 \% \\
\text { Intervensi manusia dalam } \\
\text { waktu }<12 \text { bulan }\end{array}$ \\
\hline $\begin{array}{l}\text { Kematian } \\
\text { 1orang; Cacat } \\
\text { permanen } \\
>1 \text { orang }\end{array}$ & $\geq 50 \mathrm{mSv}$ pertahun & $\begin{array}{c}500<\text { dosis } \\
<5000 \text { mSv per } \\
\text { tahun }\end{array}$ & $\begin{array}{l}\text { Dapat dipulih kan dengan } 30 \% \leq \mathrm{X}<50 \% \\
\text { intervensi manusia dalam } \\
\text { waktu lama }>12 \text { bulan }\end{array}$ \\
\hline $\begin{array}{l}\text { Kematian lebih } \\
\text { dari } 1 \text { orang }\end{array}$ & $\begin{array}{l}\text { Terdapat } \\
\text { kontamiasi }\end{array}$ & $\begin{array}{c}\geq 5000 \mathrm{mSv} \\
\text { pertahun }\end{array}$ & $\begin{array}{l}\text { Tidak dapat dipulihkan } \\
\text { dengan } \\
\text { cara apapun }\end{array}$ \\
\hline
\end{tabular}


Dengan memperoleh nilai $\mathrm{R}$ berdasarkan perhitungan pada persamaan 1 (satu) maka dapat diketahui berapa peringkat risiko pada suatu kegiatan dengan menggunakan Tabel 3. Dari Pe-meringkatan risiko ini, maka setiap kegiatan dapat dinilai kelayakannya dan dapat dilakukan pengendalian kegiatan-nya berdasarkan nilai yang diperoleh pada Tabel 3.
Adapun pengendalian risiko dapat dilakukan dengan 5 (lima) cara yaitu :

- Eliminasi (penghilangan potensi bahaya);

- Substitusi (penggantian bahan/alat/ metode);

- Pengendalian dengan rekayasa:

- Pengendalian administrative, serta

- Penggunaan alat pelindung diri (APD).

Tabel 3. Pemeringkatan risiko

\begin{tabular}{ccl}
\hline Peringkat & $\begin{array}{c}\text { Skala } \\
\text { Risiko }\end{array}$ & \multicolumn{1}{c}{ Kesimpulan } \\
\hline A & $0-24$ & $\begin{array}{l}\text { Risiko dapat diterima, langkah pengendalian } \\
\text { dinilai efektif }\end{array}$ \\
\hline B & $25-49$ & $\begin{array}{l}\text { Risiko belum dapat diterima, perlu dilakukan } \\
\text { tindakan pengendalian tambahan }\end{array}$ \\
\hline C & $50-74$ & $\begin{array}{l}\text { Risiko tidak dapat diterima, harus dilakukan } \\
\text { tindakan penaendalian }\end{array}$ \\
\hline E & $75-99$ & $\begin{array}{l}\text { Risiko sangat tidak dapat diterima harus dilakukan } \\
\text { tindakan pengendalian segera }\end{array}$ \\
\hline
\end{tabular}

\section{HASIL DAN PEMBAHASAN}

Hasil perhitungan HIRADC dengan adanya revisi pada Tabel 4 dan 5, maka perhitungan HIRADC pada Tabel 8 akan terjadi perubahan profil dari "B" menjadi "C", seperti ditunjukkan pada Tabel 9. Kondisi ini sangat dipengaruhi oleh adanya perubahan 5 (lima) konsekuensi menjadi 3 (tiga) konsekuensi. Dari hasil ini maka terjadi perubahan mendasar pada penetapan konsekuensi K2, dimana sebelum revisi $\mathrm{K} 1$ dan $\mathrm{K} 2$ mempunyai range $\leq 5 \mathrm{mSv}$ pertahun dan $\leq 20 \mathrm{mSv}$ pertahun serta berlaku untuk penetapan skala yang lebih besar (Tabel 5) serta perubahannya pada Tabel 9.Untuk dapat memahami perubahan secara lengkap, pada pembahasan ini dilakukan dengan memberikan contoh HIRADC terhadap perubahan nilai $R$ (risiko) akibat perubahan Tabel 2 menjadi Tabel 5 serta pengaruhnya terhadap nilai pemeringkatan Risiko yang ditunjukkan pada Tabel 6. 
Tabel 4. Perubahan pada isi Sub.bab Pedoman Penilaian Risiko Keselamatan dan Kesehatan Kerja.

\begin{tabular}{lll}
\hline $\begin{array}{l}\text { Sub. bab Perka BATAN No. } \\
\text { 020/KA/l/2012 }\end{array}$ & \multicolumn{1}{c}{ Revisi } & \multicolumn{1}{c}{ Keterangan } \\
\hline $\begin{array}{l}\text { 3.3.2 Skala pengukuran } \\
\text { konsekuensi }\end{array}$ & $\begin{array}{l}4.4 .2 \text { Pengukuran } \\
\text { skala konsekuensi }\end{array}$ & $\begin{array}{l}\text { Pengurangan konsekuensi } \\
\text { dari } 5 \text { konsekuensi menjadi } 3 \\
\text { konsekuensi }\end{array}$ \\
\hline 3.3.3 Perhitungan risiko & $\begin{array}{l}\text { 4.4.3 Perhitungan } \\
\text { risiko }\end{array}$ & Perubahan skala risiko \\
\hline
\end{tabular}

Tabel 5. Penentuan skala konseksuensi, perubahan Sub.bab 3.3.2 menjadi Sub. bab 4.4.2 tentang pengukuran skala konsekuensi draft revisi pedoman penilaian risiko keselamatan dan kesehatan kerja

\begin{tabular}{|c|c|c|c|}
\hline Skala & $\begin{array}{c}\text { Dampak } \\
\text { K3 } \\
\left(\mathbf{K}_{\mathbf{1}}\right)\end{array}$ & $\begin{array}{l}\text { Penerimaan dosis } \\
\text { individu per-tahun } \\
\text { (K2) }\end{array}$ & $\begin{array}{l}\text { Kerugian financial } \\
(f) \\
\text { (K3) }\end{array}$ \\
\hline 1 & Tindakan P3K & $\leq 20 \mathrm{mSv}$ & $f<5 \%$ \\
\hline 2 & Perawatan medis & $20<$ dosis $\leq 200 \mathrm{mSv}$ & $5 \% \leq f<15 \%$ \\
\hline 3 & $\begin{array}{l}\text { Cacat permanen } \\
1 \text { orang }\end{array}$ & $200<$ dosis $\leq 500 \mathrm{mSv}$ & $15 \% \leq f<30 \%$ \\
\hline 4 & $\begin{array}{l}\text { Kematian 1orang dan/atau } \\
\text { Cacat permanen }>1 \text { orang }\end{array}$ & $\begin{array}{c}500<\text { dosis }<5000 \\
\text { mSv }\end{array}$ & $30 \% \leq f<50 \%$ \\
\hline 5 & $\begin{array}{l}\text { Kematian lebih dari } 1 \\
\text { orang }\end{array}$ & $\geq 5000 \mathrm{mSv}$ & $f \geq 50 \%$ \\
\hline
\end{tabular}

Table 6. Perbandingan pemeringkatan, hasil reviisi (Rev) dan sebelum revisi (SRev)

\begin{tabular}{cclc}
\hline Peringkat & $\begin{array}{c}\text { Skala Risiko } \\
\text { (Rev) }\end{array}$ & \multicolumn{1}{c}{ Tindakan - Kesimpulan } & $\begin{array}{c}\text { Skala Risiko } \\
\text { (SRev) }\end{array}$ \\
\hline A & $1-5$ & $\begin{array}{l}\text { Risiko dapat diterima, langkah pengen- } \\
\text { dalian dinilai efektif }\end{array}$ & $0-24$ \\
\hline B & $6-10$ & $\begin{array}{l}\text { Risiko belum dapat diterima, perlu } \\
\text { dilakukan tindakan pengendalian } \\
\text { tambahan }\end{array}$ & $25-49$ \\
\hline C & $11-15$ & $\begin{array}{l}\text { Risiko tidak dapat iterima, harus } \\
\text { ilakukan tindakan pengendalian }\end{array}$ & $50-74$ \\
\hline D & $16-20$ & $\begin{array}{l}\text { Risiko sangat tidak dapat diterima harus } \\
\text { dilakukan tindakan pengendalian segera }\end{array}$ & $75-99$ \\
\hline E & $21-25$ & $\begin{array}{l}\text { Risiko amat sangat tidak dapat diterima, } \\
\text { kegiatan tidak dilaksanakan hingga } \\
\text { dilakukan pengendalian untuk mereduksi } \\
\text { risiko. }\end{array}$ & $100-125$ \\
\hline
\end{tabular}


Untuk memudahkan melihat perbedaan akibat adanya draft perubahan pada skala konsekuensi, maka akan diuraikan suatu contoh perhitungan HIRADC dari suatu Unit Kerja untuk kegiatan pengoperasian alat Ball Milling pada tahap pelaksanaan. Peralatan ini tidak memiliki risiko radiasi, hanya mempunyai potensi risiko terhirup bahan kimia, panas dan bising. Pada contoh ini tahapan yang digunakanan hanya pada tahap pelaksanaan pekerjaan, hal ini disebabkan pada tahap ini yang dominan dapat terjadinya insiden ataupun kecelakaan.

Contoh hasil perhitngan risiko pada tahap pelaksanaan kegiatan pada Tabel 7 dengan menggunakan Tabel 1 dan Tabel 2 serta persamaam 1, diperoleh $\mathrm{R}$ (risiko) sebesar :

$$
R=P \times(\Sigma K)=1 \times 5=5
$$

Nilai R sebesar 5 ini di lihat pada Tabel 3 untuk diketahui pemeringkatan risikonya. Sedangkan jika menggunakan draft revisi yang tertuang pada Tabel 5 dan Tabel 6, maka nilai $R$ pada tahapan penimbangan bahan akan diperoleh sebesar:

$$
R=P \times(\Sigma K)=1 \times 3=3
$$

Tabel 7. Contoh Tabel HIRADC pada tahap pelaksanaan pengoperasian alat Ball

\begin{tabular}{|c|c|c|c|c|c|c|c|}
\hline \multicolumn{8}{|c|}{ Pelaksanaan Pekerjaan : } \\
\hline \multirow{2}{*}{1} & \multirow{2}{*}{2} & \multirow{2}{*}{3} & \multirow{2}{*}{4} & \multicolumn{2}{|r|}{ Risiko } & \multirow{2}{*}{7} & \multirow{2}{*}{8} \\
\hline & & & & 5 & 6 & & \\
\hline $\begin{array}{l}\text { Penimbang } \\
\text { an bahan }\end{array}$ & $\begin{array}{l}\text { Bahan bubuk } \\
\text { terhirup }\end{array}$ & $\begin{array}{l}\text { Gangguan } \\
\text { pernafasan }\end{array}$ & $\begin{array}{l}\text { Pengendalian } \\
\text { APD ,menggunak } \\
\text { an masker dan } \\
\text { pelindung telinga }\end{array}$ & 1 & 11111 & 5 & A \\
\hline $\begin{array}{l}\text { Proses } \\
\text { milling } \\
\text { Bahan }\end{array}$ & $\begin{array}{l}\text { Ruangan panas } \\
\text { dan bising }\end{array}$ & $\begin{array}{l}\text { Gangguan } \\
\text { pendenga } \\
\text { ran dan } \\
\text { panas }\end{array}$ & $\begin{array}{l}\text { Pengenda } \\
\text { lian rekayasa } \\
\text { dan menghidup } \\
\text { kan blower }\end{array}$ & 1 & 11111 & 5 & A \\
\hline $\begin{array}{l}\text { Pengeluaran } \\
\text { Hasil milling } \\
\text { cham ber }\end{array}$ & $\begin{array}{l}\text { Panas dan terkon } \\
\text { taminasi }\end{array}$ & $\begin{array}{l}\text { Sampel } \\
\text { bereaksi } \\
\text { Dengan } \\
\text { udara luar }\end{array}$ & $\begin{array}{l}\text { Pengendalian } \\
\text { APD, me-makai } \\
\text { sarung tangan } \\
\text { dan spatula }\end{array}$ & 1 & 11111 & 5 & A \\
\hline
\end{tabular}
Milling Unit Kerja-X

Keterangan Tabel 7, 8, dan 9, angka pada kolom 1 sampai kolom 8 adalah sebagai berikut:

1. Tahapan pokok pekerjaan;

2. Potensi Bahaya;

3. Akibat Kecelakaan dan/atau Penyakit Akibat Kerja;

4. Pengendalian yang sudah dilakukan;

5. Peluang terjadinya risiko ( Tabel 1);
6. Konseksuensi (Tabel 2 dan Tabel 5);

7. Pemeringkatan risiko (Tabel 3 dan Tabel 6);

8. Profil Risiko (Tabel 6), nilai profil risiko

Dari hasil ini tidak terlihat suatu perbedaan terhadap profil risiko, karena aspek penerimaan dosis (K2, hasil rev) tidak dikenakan pada contoh. Hal berbeda akan terlihat jika hasil revisi dikenakan pada contoh kegiatan yang 
berisiko terhadap radiasi. Untuk dapat profil risiko pada Tabel 6 hasil revisi. melihat perbedaan dalam penentuan

Tabel 8. Contoh tabel HIRADC pada tahap pelaksanaan kegiatan berpotensi radiasi dari Unit Kerja-Y.

\begin{tabular}{|c|c|c|c|c|c|c|c|}
\hline \multirow[t]{2}{*}{1} & \multirow[t]{2}{*}{2} & \multirow[t]{2}{*}{3} & \multirow[t]{2}{*}{4} & \multicolumn{2}{|r|}{ Risiko } & \multirow[t]{2}{*}{7} & \multirow[t]{2}{*}{8} \\
\hline & & & & 5 & 6 & & \\
\hline $\begin{array}{l}\text { Memasukkan bahan } \\
\text { bakar baru ke teras } \\
\text { dengan handling tool } \\
\text { dan crane }\end{array}$ & $\begin{array}{l}\text { Bahaya ergonomik } \\
\text {,bahaya fisik } \\
\text { (tercebur ke kolam } \\
\text { reaktor) }\end{array}$ & $\begin{array}{l}\text { Kelela han } \\
\text { dan } \\
\text { kontamina } \\
\text { si }\end{array}$ & $\begin{array}{l}\text { APD, } \\
\text { admini stratif } \\
\text { (SOP) }\end{array}$ & & $\begin{array}{l}1+1+1+1+12 \\
2+2+3+3+51\end{array}$ & $\begin{array}{l}25 \\
15\end{array}$ & $B$ \\
\hline $\begin{array}{l}\text { Pengawasan pelak } \\
\text { sanaan PPET oleh staff } \\
\text { Subbid. Keselamatan } \\
\text { Operasi }\end{array}$ & $\begin{array}{l}\text { Bahaya fisik } \\
\text { (radiasi), Bahaya } \\
\text { psikososial } \\
\text {,bahaya } \\
\text { ergonomik }\end{array}$ & $\begin{array}{l}\text { Efek stokas } \\
\text { tik, gelisah } \\
\text { dan kelela } \\
\text { han }\end{array}$ & $\begin{array}{l}\text { APD, } \\
\text { administratif } \\
(\mathrm{SOP})\end{array}$ & $\begin{array}{l}5 \\
5\end{array}$ & $\begin{array}{l}2+2+1+1+24 \\
1+1+1+1+12 \\
1+1+1+1+12\end{array}$ & 25 & $\begin{array}{l}B \\
B\end{array}$ \\
\hline $\begin{array}{l}\text { Pemasangan } \\
\text { steker drive unit } \\
\text { batang kendali, uji } \\
\text { waktu jatuh batang } \\
\text { kendali. }\end{array}$ & $\begin{array}{l}\text { Bahaya fisik } \\
\text { (radiasi), bahaya } \\
\text { fisik (tercebur ke } \\
\text { kolam reaktor, } \\
\text { bahaya psikoso } \\
\text { sial dan bahaya } \\
\text { ergonomik }\end{array}$ & $\begin{array}{l}\text { Efek stokas } \\
\text { tik, } \\
\text { kontaminas } \\
\text { i, gelisah } \\
\text { dan } \\
\text { kelelahan }\end{array}$ & $\begin{array}{l}\text { APD, } \\
\text { Admin istratif } \\
\text { (SOP) }\end{array}$ & 1 & $\begin{array}{l}2+2+1+1+2 \\
2+2+3+3+5 \\
1+1+1+1+1 \\
1+1+1+1+1\end{array}$ & $\begin{array}{l}40 \\
15 \\
25 \\
25\end{array}$ & B \\
\hline $\begin{array}{l}\text { Kekrisan dengan syarat } \\
\text { tersedia konfigurasi } \\
\text { teras baru, waktu jatuh } \\
\text { batang kendali, PSO, } \\
\text { memasukkan } 5 \text { buah } \\
\text { bahan bakar ke teras } \\
\text { reactor (langkah } 1 \mathrm{~s} / \mathrm{d} \\
\text { 5) Kritiskan reaktor } \\
\text { pada daya rendah, dan } \\
\text { Shut-down reactor }\end{array}$ & $\begin{array}{l}\text { Bahaya fisik } \\
\text { (radiasi), bahaya } \\
\text { psikososial } \\
\text { bahaya ergonomic } \\
\text { dan bahaya fisik } \\
\text { (tercebur ke kolam } \\
\text { reaktor) }\end{array}$ & $\begin{array}{l}\text { Efek } \\
\text { stokas tik, } \\
\text { konta } \\
\text { minasi, } \\
\text { gelisah dan } \\
\text { kelela } \\
\text { hand dan } \\
\text { kontami } \\
\text { nasi }\end{array}$ & $\begin{array}{l}\text { APD, } \\
\text { Administratif } \\
\text { (SOP), } \\
\text { rekayasa } \\
\text { (pasang } \\
\text { switch } \\
\text { pengaman) }\end{array}$ & 5 & $1+1+1+1+1$ & 40 & $B$ \\
\hline $\begin{array}{l}\text { Pemuatan } \\
\text { reaktivitas lebih : } \\
\text { Pemuatan } \\
\text { teras langkah ke } 6 \\
\text { hingga langkah } 12 \text { dan } \\
\text { Uji stuck rod dengan } \\
\text { menaikkan JDA } 07\end{array}$ & $\begin{array}{l}\text { Bahaya fisik } \\
\text { (radiasi) Bahaya } \\
\text { fisik (tercebur ke } \\
\text { kolam reaktor) } \\
\text { Bahaya psikoso } \\
\text { sial, Bahaya } \\
\text { ergonomik }\end{array}$ & $\begin{array}{l}\text { Efek } \\
\text { stokastik, } \\
\text { kontamina } \\
\text { si, gelisah } \\
\text { dan kelela } \\
\text { han }\end{array}$ & $\begin{array}{l}\text { APD, } \\
\text { Administratif } \\
\text { (SOP) }\end{array}$ & 5 & $\begin{array}{l}2+2+1+1+2 \\
2+2+3+3+5 \\
1+1+1+1+1 \\
1+1+1+1+1\end{array}$ & 40 & B \\
\hline
\end{tabular}

Secara umum penilaian tahapan ini dengan versi sebelum revisi peringkat risikonya adalah B (Risiko belum dapat dapat diterima, perlu dilakukan tindakan pengendalian tambahan. 
Dengan menggunakan perhitungan revisi, dimana $\mathrm{K} 2$, $\mathrm{K} 3$ dan $\mathrm{K} 4$ di konvolusi menjadi K2 pada versi revisi, maka nilai perhitungan risiko terfokus pada pada K2, yaitu batas paparan radiasi yang akan diterima oleh pekerja. Pada Tabel 9 ditunjukkan perhitungan perbandingan versi sebelum dan sesudah revisi. Untuk memudahkan perhitungan hanya diambil kolom 5 s/d 7 untuk melihat perubahan angka pada kolom 7 sehingga dapat dihitung peringkat risikonya pada kolom 9 .
Hal yang perlu dicermati dalam perubahan ini adalah menentukan range paparan radiasi pada tahapan proses ini. Sebagai contoh jika pada Tabel 9 dirubah menjadi versi revisi, dengan asumsi mengambil konsekuensi terbesar pada nilai yang terbesar dari $\mathrm{K} 2$, K3 dan $\mathrm{K} 4$, serta tidak adanya perubahan nilai pada peluang terjadinya risiko, maka akan diperoleh hasil yang sangat signifikan seperti terlihat pada Table 9 versi setelah revisi.

Tabel 9. Hasil perbandingan pemeringkatan risiko, sebelum revisi (SRev) dan setelah revisi (Rev, cetak miring)

\begin{tabular}{|c|c|c|c|c|c|c|c|}
\hline \multicolumn{4}{|c|}{ Penilaian risiko sebelum revisi ((SRev) } & \multicolumn{4}{|c|}{ Penilaian risiko sebelum revisi (Rev) } \\
\hline \multicolumn{2}{|c|}{ Risiko } & \multirow[t]{2}{*}{7} & \multirow[t]{2}{*}{8} & \multicolumn{2}{|c|}{ Risiko } & \multirow[t]{2}{*}{7} & \multirow[t]{2}{*}{8} \\
\hline 5 & 6 & & & 5 & 6 & & \\
\hline 5 & $1+1+1+1+1$ & 25 & $B$ & 5 & $1+1+1$ & 15 & C \\
\hline 1 & $2+2+3+3+5$ & 15 & A & 1 & $2+2+5$ & 9 & B \\
\hline 5 & $2+2+1+1+2$ & 40 & $B$ & 5 & $2+2+2$ & 30 & Over \\
\hline 5 & $1+1+1+1+1$ & 25 & B & 5 & $1+1+1$ & 15 & C \\
\hline 5 & $1+1+1+1+1$ & 25 & B & 5 & $1+1+1$ & 15 & C \\
\hline 5 & $2+2+1+1+2$ & 40 & $B$ & 5 & $2+2+2$ & 30 & Over \\
\hline 1 & $2+2+3+3+5$ & 15 & $A$ & 1 & $2+3+5$ & 10 & $B$ \\
\hline 5 & $1+1+1+1+1$ & 25 & B & 5 & $1+1+1$ & 15 & C \\
\hline 5 & $1+1+1+1+1$ & 25 & B & 5 & $1+1+1$ & 15 & $C$ \\
\hline 5 & $2+2+1+1+2$ & 40 & $B$ & 5 & $2+2+2$ & 30 & Over \\
\hline 5 & $1+1+1+1+1$ & 25 & $B$ & 5 & $1+1+1$ & 15 & C \\
\hline 5 & $1+1+1+1+1$ & 25 & $B$ & 5 & $1+1+1$ & 15 & C \\
\hline 1 & $2+2+3+3+5$ & 15 & A & 1 & $2+3+5$ & 10 & B \\
\hline 5 & $2+2+1+1+2$ & 40 & $B$ & 5 & $2+2+2$ & 30 & Over \\
\hline 1 & $2+2+3+3+5$ & 15 & $A$ & 1 & $2+3+5$ & 9 & $B$ \\
\hline 5 & $1+1+1+1+1$ & 25 & $B$ & 5 & $1+1+1$ & 15 & C \\
\hline 5 & $1+1+1+1+1$ & 25 & $B$ & 5 & $1+1+1$ & 15 & C \\
\hline
\end{tabular}

Dengan asumsi ini, maka setiap nilai > 26 pada pemeringkatan risiko pada Tabel 6 (Profil Risiko) tidak dapat dilakukan karena melebihi range $21 \mathrm{~s} / \mathrm{d}$ 25 (risiko amat sangat tidak dapat diterima, kegiatan tidak dilaksanakan hingga dilakukan pengendalian untuk mereduksi risiko). Hal ini dapat terjadi disebabkan asumsi penetapan skala risiko untuk daerah kerja yang berpotensi 
radiasi yang besar dan penetapan skala konsekuensi diambil yang terbesar (konvolusi K2, K3 dan K4) menjasi K2 pada revisi perka ini. Untuk mengatasi angka pada penilaian risiko versi revisi, maka peran menentukan Tabel 1 tentang Skala Peluang terjadinya risiko dan harus ditinjau ulang dan Tabel 5 tentang Penentuan Skala Konseksuensi (K) yang mengalami perubahan pada Sub.bab 3.3.2 menjadi Sub.bab 4.4..2 tentang pengukuran skala konsekuensi pada draft revisi pedoman penilaian risiko keselamatan dan kesehatan kerja. Dua hal inilah yang menyebabkan meningkatnya nilai pada Pemeringkatan risiko Tabel 6 (Profil Risiko ).
Tinjauan terhadap HIRADC memang harus dilakukan, hal ini sesuai dengan klausul 3.2.1. pada Standar Batan Nomor SB006 OHSAS 18001: 2008 tentang persyaratan Sistem Manajemen Keselamatan dan Kesehatan Kerja. Hal ini harus dilakukan disebabkan jika terjadi sesuatu kecelakaan, maka penelusuran akan dimulai dari penetapan identifikasi bahaya dan penilaian risiko, serta penerapan Sistem Manajemen Batan, seperti yang ditunjukkan pada Gambar 1.

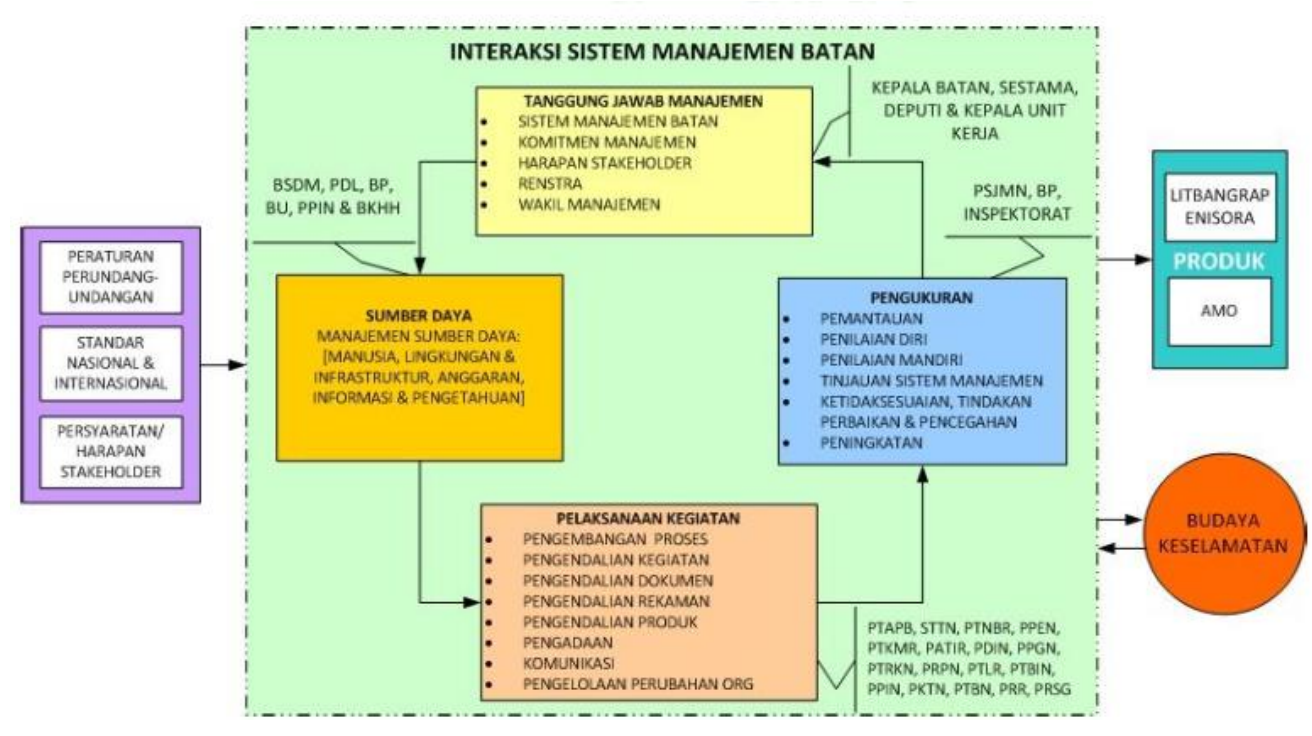

Gambar 1. Interaksi bahaya (risk) terhadap pelaksanaan SMK3 ${ }^{[5]}$.

Pada Gambar 1 terlihat bahwa pelaksanaan interaksi terhadap HIRADC merupakan tanggung jawab Unit Kerja Teknis. Hal ini juga sesuai dengan Pasal 9 ayat 3 butir b yang menyatakan bahwa dalam menyusun rencana K3 sebagai- mana dimaksud pada ayat (2) pengusaha (organisasi/Unit Kerja) harus mempertimbangkan identifikasi potensi bahaya, penilaian, dan pengendalian risiko ${ }^{[5]}$. Hal yang perlu menjadi perhatian bahwa dokumen HIRADC 
menjadi penting adalah terkait tanggung jawab dan tanggung gugat pada saat terjadinya suatu kecelakaan, penyelidikan dan pemulihan maupun keadaan kedaruratan.

\section{KESIMPULAN DAN SARAN}

\section{Kesimpulan}

Adanya perubahan 5 (lima konsekuensi) menjadi 3(tiga) konsekuensi akan berkontribusi besar terhadap penilaian pada profil pemneringkatan risiko. Dengan perubahan ini maka nilai profil risiko bagi kegiatan rutin dan non-rutin yang berpotensi radiasi akan cenderung meningkat. Untuk itu jika revisi Peraturan Kepala Batan No. 020//KA/l/2012 tentang Pedoman Penilaian Risiko Keselamatan dan Kesehatan Kerja akan diterapkan maka perlu dilakukan antara lain:

1. HIRADC untuk kegiatan berpotensi radiasi akan cenderung meningkat terhadap nilai risiko;

2. Mengkaji ulang HIRADC yang sudah dibuat dengan memperhitungkan dengan seksama dan cermat dalam menentukan Tabel 1 tentang Skala peluang terjadinya risiko dan penetapan skala konseksuensi pada Tabel 5;

3. Memperhatikan tanggung jawab dan tanggung gugat merupakan bagian tugas manajemen dan pelaksana, maka perlu dilakukan kajian terhadap HIRADC secara berkala.

4. Adanya perubahan ini jika diberlakukan, maka akan mendorong kepatuhan individu dalam melaksanakan peraturan perundangan dan merupakan bagian proses internalisasi budaya keselamatan.

\section{Saran}

1. Jika kecenderungan profil keselamatan meningkat, maka disarankan range pada $\mathrm{K} 2$ diperluas sehingga profil masih dapat diterima pada skala risikonya;

2. Disarankan memberikan lampiran pada konsekuensipada kerugian financial pada K3 (versi revisi).

\section{DAFTAR PUSTAKA}

1. BATAN, Standar Batan Nomor SB006 OHSAS 18001:2008 (2008), Persyaratan Sistem Manajemen Keselamatan dan Kesehatan Kerja, Jakarta.

2. Peraturan Kepala BATAN Nomor 020/KA/X/2012 (2012), Tentang Pedoman Penilaian Risiko Keselamatan dan Kesehatan Kerja, Jakarta.

3. Peraturan Kepala BATAN Nomor 200/KA/X/2012 (2012), tentang Pedoman Pelaksanaan Budaya Keselamatan, Jakarta.

4. Peraturan Kepala BATAN Nomor 171/KA/VII/2012 (2012), tentang Pedoman Sistem Manajemen Badan Tenaga Nuklir Nasional, Jakarta.

5. Peraturan Batan No 5 Tahun 2019 tentang Pencabutan Peraturan Kepala Badan Tenaga Nuklir Nasional Nomor 020/KA/X/2012 Tentang Pedoman Penilaian Risiko Keselamatan Dan Kesehatan Kerja (Standar Batan Bidang Administrasi, Manajemen dan Organisasi) 